\title{
The Sea Urchin Centrostephanus Tenuispinus (Clark, 1914) is an Important Bio-Eroder on a High Latitude (320 S) Coral Reef.
}

RMGN Thilakarathna ( $\nabla$ nilupikat@yahoo.com )

University of Ruhuna https://orcid.org/0000-0003-3273-0238

Mike van Keulen

Murdoch University

John K. Keesing

CSIRO Oceans and Atmosphere

\section{Research Article}

Keywords: Sea urchin, Grazing, Calcium carbonate, Bio-erosion, Coral reef

Posted Date: June 16th, 2021

DOI: https://doi.org/10.21203/rs.3.rs-591418/v1

License: (c) (1) This work is licensed under a Creative Commons Attribution 4.0 International License.

Read Full License 
1 The sea urchin Centrostephanus tenuispinus (Clark, 1914) is an important bio-eroder on a high

$2 \quad$ latitude $\left(32^{\circ} \mathrm{S}\right)$ coral reef.

3

4 Thilakarathna R.M.G.N. ${ }^{12}$ Mike van Keulen ${ }^{1}$ and John K. Keesing ${ }^{3}$

5

$6 \quad{ }^{1}$ Environmental \& Conservation Sciences, Murdoch University, Murdoch, Western Australia

$7 \quad{ }^{2}$ Department Oceanography and Marine Geology, Faculty of Fisheries and Marine Sciences \&

8 Technology, University of Ruhuna, Matara, Sri Lanka

$9{ }^{3}$ CSIRO Oceans and Atmosphere Research and University of Western Australia Oceans Institute,

10 Indian Ocean Marine Research Centre, Crawley, Australia

11

12 nilupikat@yahoo.com

13 ORCID: 0000-0003-3273-0238

14

15

16

17

18

19

20

21

22

23

24

25

26

27

28

29

30 
Abstract

32 Sea urchins are keystone herbivores in many marine benthic habitats. They can significantly influence 33 coral-algae phase shifts and impact on reef carbonate budgets through grazing. Hall Bank reef in 34 Western Australia is unique among other reefs in the region being high latitude with a high 35 hermatypic coral cover but lacking macroalgae and soft corals. Since the reef status is thought to 36 result from high densities of the urchin Centrostephanus tenuispinus limiting the growth of 37 macroalgae, the present study was focused on evaluating their role as bio-eroders. Monthly samples of 3826 urchins were collected from 2014-2016 and gut composition was analyzed. Gut evacuation rates 39 were calculated using 50 urchins dissected at time intervals $(0,4,8,16,24,36,48,60,72$ and $96 \mathrm{~h})$.

40 Reworked calcium carbonate was calculated using 30 urchins maintained in five cages in a seagrass 41 bed adjacent to the reef site. Mean percentages for organic component, calcium carbonate and other 42 siliceous components were $86.29 \pm 3.23 \%, 10.32 \pm 2.76 \%$ and $3.39 \pm 1.52 \%$ respectively. Gut 43 evacuation rates for autumn, winter, spring and summer were $0.70,0.24,0.48$ and $0.72\left(\right.$ day $\left.^{-1}\right)$. Bio44 erosion rates were significantly higher in Summer-16 $\left(3.52 \mathrm{~g} \mathrm{CaCO}_{3} \mathrm{~m}^{-2}\right.$ day $\left.^{-1}\right)$ and lower in winter $45\left(1.32 \mathrm{~g} \mathrm{CaCO}_{3} \mathrm{~m}^{-2} \mathrm{day}^{-1}\right)(\mathrm{F}=101.580, \mathrm{p}<0.000)$. High erosion rates were recorded for large urchins $46\left(\mathrm{~F}=37.789, \mathrm{P}<0.001\right.$. Annual urchin bio-erosion was $1017.69 \mathrm{~g} \mathrm{CaCO}_{3} \mathrm{~m}^{-2} \mathrm{a}^{-1}$. Differences in food 47 ingestion rates in response to seawater temperature changes are thought to be the main cause for the 48 significant differences in seasonal bio-erosion rates.

49 Key words: Sea urchin, Grazing, Calcium carbonate, Bio-erosion, Coral reef

50

51

52

53 
Sea urchins play a vital role in many marine benthic habitats as grazers, bio-eroders, producers of particulate inorganic matter and habitat providers (Scheibling 1986; Glynn 1988; Andrew and Underwood 1989; Mokady et al. 1996; Tuya et al. 2004; Mamelona and Pelletier 2005; Bluhm et al. 2009; Glynn and Manzello 2015; Glynn et al. 2017). As grazers, the influence of sea urchins can be immense as they prevent the growth of all organisms other than encrusting algae. High densities of sea urchins remove competitive algae, reducing coral mortality due to algal overgrowth and allowing corals to increase in size and abundance (Bluhm et al. 2009). Thus, they significantly contribute to the interplay between seaweed and coral-dominated reefs. Although they are well known to be keystone grazers and studied extensively, their grazing habits and their role as bio-eroders in many habitats is understudied.

Sea urchins can weaken carbonate reefs through spine abrasion and through scraping hard carbonate substrate with their tooth-like feeding plates, the Aristotle's lantern (Klinger and Lawrence 1985; Ma et al. 2008). These organisms, being one of the major causative agents of bio-erosion play a critical role in shaping reef structure and producing sediments that characterise the reef environment (Scheibling 1986; Glynn 1988; Bak 1994; Mokady et al. 1996; Tuya et al. 2004; Dumont et al. 2013; Glynn and Manzello 2015). Due to this immense impact on their habitats, they are considered "reef engineers". Urchins can exert severe pressure on reefs with shifts from fish bio-eroders to urchin bioeroders resulting in marked impacts on reef community assemblages because of their grazing pressure, depending on the density of the urchin population (McClanahan et al. 1994). Although they contribute to the balance between reef constructive and destructive processes, overgrazing, with ingestion of large quantities of reef carbonates, can negatively impact reef structure. Glynn (1988) recorded bioerosion of $40 \mathrm{~kg} \mathrm{CaCO}_{3} \mathrm{a}^{-1}$, which exceeded reef accretion rates $\left(0.3-12 \mathrm{~kg} \mathrm{CaCO}_{3} \mathrm{a}^{-1}\right)$ in tropical reefs. Urchins have been estimated to contribute up to $80 \%$ of total erosion of reefs (Scoffin et al. 1980).

Although coral reef growth has been the focus of many biological studies, reef destruction by

87 bio-erosion has received little attention (Tribollet et al. 2002). Considering the ecological role and impact of urchins on their habitat, quantification of this impact is essential for the management of many marine habitats. Urchin bio-erosion can equal or exceed reef carbonate production (Bak 1994). Higher average rates of bio-erosion by sea urchins have been reported on reef slopes $\left(0.9 \mathrm{~kg} \mathrm{CaCO}_{3}\right.$ 
$\left.91 \mathrm{~m}^{-2} \mathrm{a}^{-1}\right)$ compared to reef flats $\left(0.5 \mathrm{~kg} \mathrm{CaCO}_{3} \mathrm{~m}^{-2} \mathrm{a}^{-1}\right)$ (Mokady et al. 1996). Thus, the extent of bio-

92 erosion can vary due to habitat structure. The extent of sea urchin bio-erosion mainly depends on

93 species, test size/diameter and population density (Bak 1994). Diadema antillarum has been reported

94 to cause erosion of $4.6 \mathrm{~kg} \mathrm{CaCO}_{3} \mathrm{~m}^{-2} \mathrm{a}^{-1}$ in a patch reef at St. Croix, Virgin Islands, US (9 individuals $95 \mathrm{~m}^{-2}$ ), and $5.3 \mathrm{~kg} \mathrm{CaCO}_{3} \mathrm{~m}^{-2} \mathrm{a}^{-1}$ in fringing reefs at Barbados (23 individual $\left.\mathrm{m}^{-2}\right)$. Carreiro-Silva and

96 McClanahan (2001) stated that, despite similar body sizes, bio-erosion can vary due to different

97 feeding behaviours (species-specific feeding strategies). The outcomes of these studies imply the need

98 for species-specific studies on bio-erosion in unique sea urchin-dominated habitats. Currently, all

99 studies focused on bio-erosion have been centred on tropical reefs, mainly Caribbean and Indo-pacific regions; reefs in higher latitudes have not been studied. southern Western Australia is unique due to its high hermatypic coral cover (mean $=52.6 \pm 4.65 \%$ ), and scarcity of soft coral and macroalgae (Thomson and Frisch 2010). In general, reefs in this area are dominated by kelps and other macro-phaeophtyes and grazing herbivores exert little influence (Vanderklift and Kendrick 2004; Vanderklift and Kendrick 2005; Vanderklift et al. 2009) resulting instead on an abundance of drift algae which is the major food sources of large abundant herbivores such as the urchin Heliocidaris errythrogramma (Vanderklift and Kendrick; 2005; Vanderklift and Wernberg 2008) and the abalone Halitois roei (Wells and Keesing 1989). On the other hand, Centrostephanus tenuispinus, the focus of this study, is regarded as a predominantly a grazer rather than a drift feeder (Vanderklift and Kendrick; 2005; Vanderklift and Wernberg 2008). Thomson and Frisch (2010) suggested that the high abundance of herbivorous sea urchin Centrostephanus tenuispinus (mean density $=5.0 \pm 0.81 \mathrm{~m}^{-2}$ ) may contribute to the maintenance of the high cover of corals at Hall Bank. Main objective of this study is to quantify bio- erosion of C. tenuispinus and to assess its role in reef structuring process.

2.0 Methodology

Hall Bank reef $\left(32^{\circ} 2.002^{\prime} \mathrm{S}\right.$ and $\left.115^{\circ} 42.957^{\prime} \mathrm{E}\right)$ is located $3 \mathrm{~km}$ northwest of the Fremantle

119 Harbour in southern Western Australia (Figure 1). It is a small patch of limestone reef (around 2 ha)

120 dominated by scleractinian corals (mostly family Faviidae), depth 7-10 m, which abruptly descends to 
121 the surrounding seagrass bed (depth $15 \mathrm{~m}$ ). The study was conducted from December 2014 to 122 February 2016.

2.1. Analysis of calcium carbonate in urchin gut contents

Sea urchins were collected (26 individuals per month) from December 2014 to February 2016. Samples were transported to the laboratory in Murdoch University on ice. Test diameter $( \pm 0.1$ $\mathrm{mm})$ and wet weight $( \pm 0.001 \mathrm{~g})$ were measured. Urchins were dissected and gut contents extracted to determine the amount of calcium cabonate and organic content using the methods described by Carreiro-Silva and McClanahan (2001). Gut contents were dried to constant weight in a preheated ovenset at $70^{\circ} \mathrm{C}$ for $48 \mathrm{~h}$. Subsamples of $1 \mathrm{~g}$ of the gut contents were weighed on a high precision analytical balance $( \pm 0.0001 \mathrm{~g})$ and immediately transfered to a muffle furnace for $5 \mathrm{~h}$ at $500{ }^{\circ} \mathrm{C}$ to combust the organic matter. Samples were weighed and digested with $5 \% \mathrm{HCl}$. Residual matter was filtered with preweighed filter paper under suction, dried $\left(70^{\circ} \mathrm{C}\right.$ for $\left.8 \mathrm{~h}\right)$ and weighed.

\subsection{Determination of newly eroded calcium carbonate}

Thirty urchins were caged $(1 \times 1 \times 1 \mathrm{~m})$ in 5 cages $(6$ urchins per cage $)$ in a seagrass bed adjacent to the Hall Bank reef. Cages were kept underwater for 2 months. After the cage experiment, urchins were collected and transferred on ice to the laboratory, where they were dissected, and gut contents removed into aluminum dishes. The amount of $\mathrm{CaCO}_{3}$ in the guts was analyzed using the methods described above. Newly eroded $\mathrm{CaCO}_{3}$ was calculated as follows: evacuation rates for autumn and spring were calculated using the values of summer and winter with respect to the mean sea temperature. Fifty sea urchins were collected for each trial. Five urchins were

149 kept in a flow-through seawater aquarium (temperature-controlled $17{ }^{\circ} \mathrm{C}$ in winter and $22{ }^{\circ} \mathrm{C}$ in summer). These urchins were sacrificed at 4, 8, 12, 16, 24, 36, 48, 72 and 96 hourly intervals. Urchins 

were dried for $24 \mathrm{~h}$ in an oven set at $70^{\circ} \mathrm{C}$ and weighed. Mean values $(\mathrm{n}=5)$ for dry gut-weight were plotted against time. The relationship between dry weight and time was defined by the following regression equation: $C=C_{0} e^{-R T}$

156 Where $C=$ gut content weight; $C_{0}=$ gut content at time $0 ; \mathrm{t}=$ time; $\mathrm{R}=$ rate of decrease

158 Meantime (t) for gut evacuation was calculates using Elliott (1972).

$\bar{t}=\int_{0}^{\infty} \frac{C_{0} e^{-R T} d t}{C_{0}}=\frac{1}{R}$

Daily calcium carbonate and algae ingestion were calculated using the below equation.

where $\mathrm{F}=$ Food consumption rate

\section{4 Analysis of sea urchin density}

Ten haphazard transects $(20 \times 1 \mathrm{~m})$ were sampled on the reef in each season (autumn 2015, winter 2015, spring 2015 and summer 2016). The number of urchins in each transect was counted, and the density was calculated as individuals per square meter.

2.5 Measurements of bio-erosion rates

Food ingesion rate $=$ Daily ingestion rate $\left(\right.$ day $\left.^{-1}\right) X$ Dry gut content $(g) \ldots .5$

Bioerosion rate $=$ Daily ingesion rate $\left(\right.$ day $\left.^{-1}\right) X$ Newly eroded $\mathrm{CaCO}_{3}$ weight $(\mathrm{g}) \ldots . .6$

176 2.6 Statistical Analysis

All sea urchin samples were categorised into three different size classes depending on test

178 diameter: $<65 \mathrm{~mm}, 65-70 \mathrm{~mm}$ and $>70 \mathrm{~mm} . \mathrm{CaCO}_{3}$ percentages and bio-erosion rates were compared 
with respect to seasonal variation and test size using two-way analysis of variance (ANOVA). All statistical tests were carried out in SPSS software (SPSS 24).

3.0 Results

3.1 Analysis of calcium carbonate in urchin gut contents

Gut content composition analysis revealed that urchins ingested $86.29 \pm 3.23 \% \mathrm{CaCO}_{3}, 10.32$

$\pm 2.76 \%$ organic matter and $3.39 \pm 1.52 \%$ other inorganic components (overall mean $\pm \mathrm{SD}$ ). Mean $\mathrm{CaCO}_{3}$ content $(83.83 \pm 3.73 \%)$ was significantly lower in summer 2015 than other seasons $($ ANOVA, $\mathrm{F}(4,364)=17.811, \mathrm{P}<0.001)$. No significant differences in mean $\mathrm{CaCO}_{3}$ content were observed between other seasons. Calcium carbonate content did not vary between test size classes $($ ANOVA, $F(2,364)=1.645, \mathrm{P}=0.195)($ Figure 2$)$.

3.2 Determination of newly eroded calcium carbonate

The mean percentage composition of $\mathrm{CaCO}_{3}$, organic and other inorganic components of the caged urchins (in seagrass bed) were $64.99 \pm 5.24 \%, 29.75 \pm 4.83 \%$ and $5.54 \pm 2.30 \%$ respectively (Figure 3). The average newly eroded $\mathrm{CaCO}_{3}$ was $22.38 \%$. The organic component of the caged urchins $(29.75 \pm 4.83 \%)$ was greater than that of the urchin population on the reef $(10.32 \pm 2.76 \%)$

3.3 Analysis of gut evacuation rate

The initial mean dry gut-weight in summer and winter was $7.125 \pm 2.18 \mathrm{~g}$ and $5.198 \pm 1.40$ $\mathrm{g}$, respectively. The gut evacuation experiment revealed that $50 \%$ of the gut is emptied within $24 \mathrm{~h}$ in summer and $36 \mathrm{~h}$ in winter. $86 \%$ and $75 \%$ of gut contents were emptied within $72 \mathrm{~h}$ in summer and in winter respectively (Figure 4). The total time for gut evacuation was $100 \mathrm{~h}$ in winter and $33.3 \mathrm{~h}$ in summer. gut-weight of $C$. tenuispinus in spring $2015(7.31 \pm 2.02)$ was significantly higher than summer 2015 $(6.48 \pm 1.33)$ and autumn $2015(6.54 \pm 1.37)($ ANOVA, $F(4,364)=4.485, \mathrm{P}=0.002)$. No significant differences were observed between other seasons (Table 1). The highest mean dry gut-weight ( $7.74 \pm$ 1.66) was observed in the large size class $(>70 \mathrm{~mm})$ and the lowest $(5.81 \pm 1.29)$ in the smallest size 
class $(<65 \mathrm{~mm})($ ANOVA, $\mathrm{F}(2,364)=55.177, \mathrm{P}<0.001)$. The gut evacuation rate was 0.72 day $^{-1}$ and 0.24 day $^{-1}$ for summer and winter respectively (Table 1). Estimated gut turnover rates for autumn and 211 spring were 0.70 day $^{-1}$ and 0.48 day $^{-1}$ respectively.

Food ingestion rates were significantly different $($ ANOVA, $\mathrm{F}(4,364)=180.999, \mathrm{P}<0.001)$ between all seasons except between summer 2015 and autumn 2015 ( $\mathrm{P}=0.978)$, summer 2015 and summer $2016(\mathrm{P}=0.073)$. Differences in food ingestion rates varied among the three size classes independently of the season (ANOVA, F $(2,364)=47.460, \mathrm{P}<0.001)$. Mean food ingestion rates for size classes $<65 \mathrm{~mm}, 65-70 \mathrm{~mm}$ and $>70 \mathrm{~mm}$ was $3.33 \pm 1.28 \mathrm{~g} \mathrm{day}^{-1}, 3.80 \pm 1.46 \mathrm{~g}^{-1 a y}{ }^{-1}, 4.25 \pm 1.79$ g day $^{-1}$ respectively.

3.4 Measurements of bio-erosion rates

The highest daily bio-erosion rate $\left(1.10 \pm 0.36 \mathrm{~g} \mathrm{CaCO}_{3}\right.$ individual ${ }^{-1}$ day $\left.^{-1}\right)$ was recorded in summer 2016 and the lowest $\left(0.36 \pm 0.09 \mathrm{~g} \mathrm{CaCO}_{3}\right.$ individual $^{-1}$ day $\left.^{-1}\right)$ was recorded in winter 2015 (Table 2). Differences in daily bio-erosion rates were significant between seasons (ANOVA, F $(4,364)$ $=101.580, \mathrm{P}<0.000)$ and urchin size classes $($ ANOVA, $\mathrm{F}(2,364)=37.789, \mathrm{P}<0.001)$. Bio-erosion rates were not significantly different between summer 2016 and autumn 2015 ( $\mathrm{P}=0.077)$.

Seasonal bio-erosion rates were higher in autumn 2015 and summer 2016 (314.64 g of $\mathrm{CaCO}_{3} \mathrm{~m}^{-2}$ and $316.80 \mathrm{~g}$ of $\mathrm{CaCO}_{3} \mathrm{~m}^{-2}$ respectively) than that of other seasons (Table 3). $C$. tenuispinus was responsible for annual erosion of $1017.69 \mathrm{~g}_{\text {of }} \mathrm{CaCO}_{3} \mathrm{~m}^{-2 \mathrm{a}-1}$ at Hall Bank reef.

Sea urchins are considered as reef engineers due to their ability to influence their habitat, in particular destructive grazing of macrophytes and erosion of reefs. The grazing of $C$. tenuispinus on the high latitude coral reef at Hall Bank is believed to exert a structuring influence by excluding the development of a macroalgal canopy and instead favouring a high cover of scleractinian corals (Thomson and Frisch 2010), This study revealed that the gut contents of $C$. tenuispinus were mainly composed of $\mathrm{CaCO}_{3}(86.6 \pm 0.96 \%)$. Only $10.84 \pm 0.52 \%$ of the gut contents was organic components. Similar studies in other regions of the world have documented the same outcome, having 237 higher percentages of calcium carbonates (Carreiro-Silva and McClanahan 2001; Brown-Saracino et al. 2007). Carreiro-Silva and McClanahan (2001) stated that Diadema setosum, Diadema savygnyi and 
Echinothrix diadema consumed over $80 \%$ calcium carbonate, and only $8 \%$ organic components. Hall

240 Bank reef lacks established macroalgal beds, probably due to the competition for space from corals

241 and intensive grazing of any algal recruitment. Urchins therefore totally depend on turf algae and occasional drifting algae. Based on stable isotope analysis, C. tenuispinus is an omnivore which feed on both algae and animal matter (Vanderklift et al. 2006). Centrostephanus tenuispinus are known to be predominantly grazers (Vanderklift and Kendrick; 2005; Vanderklift and Wernberg 2008) Analysis of gut contents in this study revealed that $C$. tenuispinus on Hall Bank Reef mainly feed on turf algae as well as microinvertebrates (Thilakarathna 2017). Thus, the organic component in the gut 247 corresponds not only to the grazed algae but also to invertebrate tissues. Urchins from the correction factor experiment had a higher percentage of organic components $(29.71 \pm 1.44 \%)$, than urchins on the reef, mainly due to the availability of seagrass. Most of the $\mathrm{CaCO}_{3}$ material was derived from encrusting coralline algae and coral substrate. Mollusc shells (snails and bivalves) were also noted during the analysis, although difficult to quantify; a small portion of these mollusc shells might contribute to the total weight of calcium carbonates. Presence of other inorganic substances including calcareous material and rock fragments in C. tenuispinus guts is indicative of their active grazing (Vanderklift et al. 2006).

Organic components make up one-fifth of the daily calcium carbonate consumption in many studied tropical sea urchins (Carreiro-Silva and McClanahan 2001), yet organic components in $C$. tenuispinus from this study was only one-eighth of daily calcium carbonate consumption. The low proportion of organic material in urchin's guts suggests that this herbivore assemblage is food-limited. Hall Bank reef is devoid of macroalgae (Thomson and Frisch 2010). Analysis of organic components in the urchin gut indicates that they mainly depend on turf algae (Thilakarathna 2017). Urchin species, test size, and population density mainly influence grazing and bio-erosion by sea urchins (Bak 1994). Research conducted on Diadema antillarum in western Mexico revealed that there is a positive correlation between test diameters and the extent of bio-erosion $(<30 \mathrm{~mm}, 0.54 \pm$ $0.45 \mathrm{~g}$ of $\mathrm{CaCO}_{3} />50 \mathrm{~mm}, 3.88 \pm 0.74 \mathrm{~g}$ of $\mathrm{CaCO}_{3}$ ) (Herrera-Escalante et al. 2005). Carreiro-Silva and McClanahan (2001) revealed the importance of urchin species and body size on grazing as well.

266 Larger Echinometra mathaei $(>30 \mathrm{~mm})$ are known to have more impact $\left(166.70 \mathrm{mg} \mathrm{day}^{-1}\right)$ on habitat 267 than smaller individuals $\left(77.78 \mathrm{mg} \mathrm{day}^{-1}\right)$ (Manullang et al. 2014). This study confirms that test size has greater impact on level of bio-erosion as well. Larger individuals had higher erosion rates $(0.932 \pm$ 


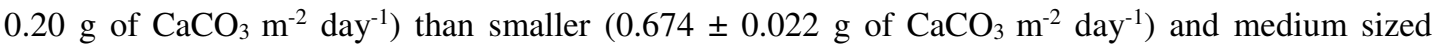
urchins $\left(0.824 \pm 0.025 \mathrm{~g}\right.$ of $\left.\mathrm{CaCO}_{3} \mathrm{~m}^{-2} \mathrm{day}^{-1}\right)(\mathrm{p}=0.000)$. Large urchins had significantly heavier and

271 larger lanterns (lantern diameter $26.20 \pm 2.20 \mathrm{~mm}$; lantern height $27.10 \pm 2.17 \mathrm{~mm}$, lantern weight $27210.40 \pm 1.78 \mathrm{~g}$ ) than small urchins (lantern diameter $21.19 \pm 1.56 \mathrm{~mm}$; lantern height $21.80 \pm 1.61$ $273 \mathrm{~mm}$, lantern weight $6.10 \pm 1.08 \mathrm{~g})(\mathrm{p}=0.000)$. The large and heavy lanterns of large urchins enable intense scraping. A positive correlation between test diameters and the extent of feeding rates and bioerosion has been witnessed for Echinometra mathaei, Tripneustes gratilla, Salmacis sphaeroides and Strongylocentrotus nudus (Klumpp et al. 1993; Kawamata 1997; Manullang et al. 2014).

It is evident that the density of the urchin population has an immense impact on structuring benthic communities and the extent of reef bio-erosion (Hereu et al. 2004; Ling and Johnson 2009).

279 High densities of urchins can cause higher levels of bio-erosion (Glynn 1988; McClanahan and Kurtis 1991; Bak 1994; Eakin 1996). Eucidaris galapagensis in reef flats of Floreana Islands and Galapagos 281 Islands is known to contribute to reef erosion of $3.320 \mathrm{~kg} \mathrm{CaCO}_{3} \mathrm{~m}^{-2} \mathrm{a}^{-1}$ and $22.332 \mathrm{~kg} \mathrm{CaCO}_{3} \mathrm{~m}^{-2} \mathrm{a}^{-1}$ with population densities of 4.6 individuals $\mathrm{m}^{-2}$ and 30.8 individuals $\mathrm{m}^{-2}$ respectively (Glynn 1988). High densities of small urchins can have a larger bio-erosion impact than low densities of larger individuals (Griffin et al. 2003). C. tenuispinus had a mean density ranging from $3.20 \pm 0.23 \mathrm{~m}^{-2}$ to $3.73 \pm 0.33 \mathrm{~m}^{-2}$ throughout the year. Annual bio-erosion caused by a density of $3.2-3.7 \mathrm{~m}^{-2} C$. tenuispinus was $1.017 \mathrm{~kg} \mathrm{CaCO}_{3} \mathrm{~m}^{-2} \mathrm{a}^{-1}$.

Most previously conducted studies on bio-erosion focused on tropical urchins; mainly Diadema, Echinometra and Echinothrix species, and these species are considered to be the most impacting bio-eroding agents in tropical reefs (Bak 1990; Mokady et al. 1996). Environmental conditions, specifically water temperature, impact the urchins' physiology, directly influencing ingestion and gut evacuation rates. Since there were no significant differences in dry gut-weight across the seasons sampled in this study, differences in ingestion rate are critical for determining the rate of bio-erosion. Significant differences in seasonal ingestion rates are mainly in response to the changes in seawater temperatures, from $17^{\circ} \mathrm{C}$ in winter to $22^{\circ} \mathrm{C}$ in summer. The gut evacuation rate was highest in summer and lowest in winter. Calculations based on mean seawater temperatures in autumn and spring indicated gut evacuation rates were 0.70 day $^{-1}$ and 0.48 day $^{-1}$. Food ingestion rates were higher in summer due to increased metabolism at higher temperatures; thus the erosion rates were higher as well. Centrostephanus tenuispinus in the current study were subjected to lower water 
temperatures $\left(17^{\circ} \mathrm{C}\right)$ in winter than in summer $\left(23^{\circ} \mathrm{C}\right)$. A difference of $6^{\circ} \mathrm{C}$ directly impacted on physiology and activity levels, and therefore changes in ingestion rates between winter and summer.

301 The highest ingestion rate recorded in this study was $5.02 \pm 1.33$ gut dry weight individual ${ }^{-1}$ day $^{-1}$ in summer 2016, which is higher than. Diadema savygnyi from tropical waters with a mean ingestion rate of $3.11 \pm 0.70 \mathrm{~g}$ gut dry weight individual ${ }^{-1}$ day $^{-1}$ (Carreiro-Silva and McClanahan 2001). At the same time D. setosum has shown an ingestion rate of $8.36 \pm 1.16 \mathrm{~g} \mathrm{day}^{-1}$ (Carreiro-Silva and McClanahan 2001). Most urchin species in the tropics experience water temperatures over $25^{\circ} \mathrm{C}$ all round year, and therefore have consistently high ingestion rates. Since the rate of bio-erosion is based on food ingestion rates, any factor affecting food intake indirectly affects the bio-erosion rate as well. The influence of water temperature on feeding has been recorded for other diadematoids as well (Coppard and Campbell 2005).

Bio-erosion calculations for both summers $(2015$ /2016) in this study were based on a gut evacuation rate of 0.72 day $^{-1}$. Mean seawater temperature was lower in summer $2015\left(22.5^{\circ} \mathrm{C}\right)$ than in summer $2016\left(23.5^{\circ} \mathrm{C}\right)$. The percentage of calcium carbonate in the guts of urchins was lower in summer 2015 than in summer 2016. The significant difference in $\mathrm{CaCO}_{3}$ ingestion rates (and hence bio-erosion) between summers may be attributed to temperature differences.

Many studies suggest that urchin feeding is affected by reproductive periods (Muthiga 2003).

316 Some urchin species feed less during spawning periods; Strongylocentrotus intermedius rarely feed 317 during their reproductive season (Fuji 1962). C. tenuispinus spawns during the winter 318 (Thilakarathna,2017). Although no significant seasonal differences of dry gut weights were observed, 319 food ingestion rate was low $\left(0.24\right.$ day $\left.^{-1}\right)$ in winter compared to the other seasons. The lowest 320 percentage of organic components was recorded in winter $(8.74 \pm 1.77 \%)$, when urchins were 321 spawning. Higher percentages of organic components were observed in autumn and summer when 322 urchin gonads are resting and initiating gametogenesis of the next cycle.

The highest mean dry gut-weight for $C$. tenuispinus was $7.31 \pm 2.02 \mathrm{~g}$, recorded in spring 2015. Diadema setosum has a similar range of test diameter and had a dry gut-weight of ( $7.05 \pm 0.98$

325 g) (Table 4). On the other hand, Diadema savygnyi, which is in the same range of test diameters, had a mean dry gut-weight of $3.48 \pm 0.78 \mathrm{~g}$ (Carreiro-Silva and McClanahan 2001). winter, which is longer than other sea urchin species, reducing to $33.3 \mathrm{~h}$ in summer. Carreiro-and 
329 McClanahan (2001) reported that the common tropical diadematoids Diadema setosum, D. savygnyi 330 and Echinothrix diadema take $20.29,26.86$ and 21.10 h respectively to empty their guts. Echinometra 331 mathaei takes $13.94 \mathrm{~h}$ to empty all gut contents (Carreiro-Silva and McClanahan 2001). The slower

332 body physiology recorded for $C$. tenuispinus in this study may be associated with low winter 333 temperatures.

334 Sea urchin feeding, and hence bio-erosion rate, is influenced by space, nature of habitat, 335 habitat structure and water temperature. Interaction of these factors causes higher bio-erosion in some habitats. It is also essential to calculate annual reef accretion rates to determine the impact of bioerosion on reef carbonate budgets.

Hall Bank reef is dominated by massive corals (Thomson and Frisch 2010) and the reef accretion rate of Hall Bank reef has not been quantified. Coral calcification rates are known to depend on seawater temperatures (Kleypas et al. 1999). Since Marmion reef is in close proximity (25 $\mathrm{km})$ to

341 Hall Bank reef and having similar seawater temperature ranges $\left(22-23^{\circ} \mathrm{C}\right)$, the calcification rate in

342 Marmion reef assumed to be similar to Hall Bank reef. The highest calcification rates were recorded 343 for Marmion for winter $2011\left(7.3 \mathrm{~g} \mathrm{~m}^{-2} \mathrm{day}^{-1}\right)$ after a marine heatwave event (Foster et al. 2014) which

344 is higher than daily bio-erosion rates in Hall Bank reef. However, calcification rates at Marmion reef 345 for summer 2012, winter 2012 and summer 2013 were (1-2.5 $\mathrm{g} \mathrm{m}^{-2}$ day $\left.^{-1}\right)$ lower than daily bio-erosion 346 rates of Hall Bank reef in both summer and autumn. Mean annual growth rates recorded for G. aspera 347 / palauensis and G. australensis in Hall Bank reef are $5.4 \pm 0.9 \mathrm{~mm} \mathrm{a}^{-1}$ and $10.9 \mathrm{~mm} \mathrm{a}^{-1}$ (Antipas 348 2013). Higher growth rates of these corals at Hall Bank reef despite its near-shore location and 349 compared to other tropical/subtropical location could be attributed to increasing trends of seawater 350 temperature. Lack of seasonality in calcification rates and slower growth of branching coral compared 351 to massive coral is known to cause by temperature anomalously occurred in 2010-2011 (Foster et al. 352 2014). Since bio-erosion is positively correlated with seawater temperature, increase in seawater 353 temperature could also lead to conditions where reef erosion rates exceed reef accretion rates, which 354 can affect the coral cover in Hall Bank reef. The absence of any measurements of calcification rates 355 on Hall Bank precludes determining a reef carbonate budget for Hall Bank reef.

356 This study only examined bio-erosion due to grazing; bio-erosion from spine abrasion has 357 not been accounted for in this study. Similarly, bio-erosion caused by other herbivores has not been 358 accounted for since $C$. tenuispinus is the main bio-eroder in this system. The difference in food 
ingestion rates in response to seawater temperature changes is the main cause for the significant differences in seasonal bio-erosion rates on Hall Bank reef and the high rates of bio-erosion likely contribute to the absence of macroalgae and the maintenance of high coral cover on Hall Bank.

\section{Compliance with Ethical Standards}

364 None of the authors does have any conflict of interests associated with this publication, and there has 365 been no significant financial support for this work that could have influenced its outcome. All 366 applicable international, national and/or institutional guidelines for sampling, care and experimental 367 use of organisms for the study have been followed and all necessary approvals have been obtained.

\section{Acknowledgement}

370 This work is part of PhD study of RMGN Thilakarathna supported by a Murdoch University

371 International Postgraduate Scholarship. Damian Thomson (CSIRO) is gratefully acknowledged for 372 providing water temperature data. Generous support with fieldwork from Steven Goynich, Michael 373 Taylor, Claudia Muller, Ian Dapson, Amy Kirke, Peter Howie, Phillip Good, and Brodee Elsdon are 374 greatly appreciated.

\section{Declarations:}

377 Conflicts of Interest/Competing Interests: None of the authors does have any conflict of interests associated with this publication, and there has been no significant financial support for this work that could have influenced its outcome.

Ethical approval: No approval of research ethics committees was required to accomplish the goals of this study because experimental work was conducted with an unregulated invertebrate species.

Consent to participate: Not applicable.

Consent for Publication: There is no conflict of interest to report. 
Author contributions: All authors, RMGN Thilakarathna, Mike van Keulen and John K. Keesing contributed to the study conception and design. Material preparation, data collection and analysis were performed by RMGN Thilakarathna under the supervision of Mike van Keulen and John K. Keesing. The first draft of the manuscript was written by RMGN Thilakarathna, and all authors commented on previous versions of the manuscript. All authors read and approved the final manuscript.

\section{List of References:}

Literature Cited

Andrew NL, Underwood AJ (1989) Patterns of abundance of the sea urchin Centrostephanus rodgersii (Agassiz) on the central coast of New South Wales, Australia. J Exp Mar Biol Ecol 131: 6180 doi http://dx.doi.org/10.1016/0022-0981(89)90011-7

Antipas KR (2013) Diversity, growth rates and population size structure of a faviid dominated 'marginal' coral reef in Fremantle, Honours dissertation. Murdoch University Western Australia

Bak R (1990) Patterns of echinoid bioerosion in two Pacific coral reef lagoons. Mar Ecol Prog Ser 66: 272

Bak R (1994) Sea urchin bioerosion on coral reefs: place in the carbonate budget and relevant variables. Coral Reefs 13: 99-103

Bluhm BA, Iken K, Hardy SM, Sirenko BI, Holladay BA (2009) Community structure of epibenthic megafauna in the Chukchi Sea. Aquat Biol 7 doi:10.3354/ab00198

Brown-Saracino J, Peckol P, Allen Curran H, Robbart M (2007) Spatial variation in sea urchins, fish predators, and bioerosion rates on coral reefs of Belize. Coral Reefs 26: 71-78 doi 10.1007/s00338-006-0159-9

Carreiro-Silva M, McClanahan TR (2001) Echinoid bioerosion and herbivory on Kenyan coral reefs: the role of protection from fishing. J Exp Mar Biol Ecol 262: 133-153 doi http://dx.doi.org/10.1016/S0022-0981(01)00288-X

Coppard S, Campbell A (2005) Distribution and abundance of regular sea urchins on two coral reefs in Fiji. Micronesica 37: 249 
Dumont CP, Lau DC, Astudillo JC, Fong KF, Chak ST, Qiu J-W (2013) Coral bioerosion by the sea urchin Diadema setosum in Hong Kong: Susceptibility of different coral species. J Exp Mar Biol Ecol 441: 71-79

Eakin CM (1996) Where have all the carbonates gone? A model comparison of calcium carbonate budgets before and after the 1982-1983 El Nino at Uva Island in the eastern Pacific. Coral Reefs 15: 109-119 doi 10.1007/bf01771900

Elliott J (1972) Rates of gastric evacuation in brown trout, Salmo trutta L. Freshwater Biology 2: 1-18

Elliott J, Persson L (1978) The estimation of daily rates of food consumption for fish. The J Anim Ecol 977-991

Foster T, Short J, Falter J, Ross C, McCulloch M (2014) Reduced calcification in Western Australian corals during anomalously high summer water temperatures. J Exp Mar Biol Ecol 461: 133143

Glynn PW (1988) El Nifio warming, coral mortality and reef framework destruction by echinoid

Fuji A (1962) Studies on the biology of the sea urchin: V. food consumption of Strongylocentrotus intermedius. Japanese J Ecol12: 181-186 bioerosion in the eastern Pacific. Galaxea 7: 129-160

Glynn PJ, Glynn PW, Reigl B (2017) El Niño, echinoid bioerosion and recovery potential of an isolated Galápagos coral reef: a modeling perspective. Mar Biol 164: 146

Glynn PW, Manzello DP (2015) Bioerosion and coral reef growth: A dynamic balance In. Birkeland c. (eds) Coral reefs in the Anthropocene. Springer, pp 67-97

Griffin S, Garcia R, Weil E (2003) Bioerosion in coral reef communities in southwest Puerto Rico by the sea urchin Echinometra viridis. Mar Biol 143: 79-84

Hereu B, Zabala M, Linares C, Sala E (2004) Temporal and spatial variability in settlement of the sea urchin Paracentrotus lividus in the NW Mediterranean. Mar Biol 144: 1011-1018

Herrera-Escalante T, López-Pérez R, Leyte-Morales G (2005) Bioerosion caused by the sea urchin Diadema mexicanum (Echinodermata: Echinoidea) at Bahías de Huatulco, Western Mexico. Rev Biol Trop 53: 263

Kawamata S (1997) Modelling the feeding rate of the sea urchin Strongylocentrotus nudus (A. Agassiz) on kelp. J Exp Mar Biol Ecol 210: 107-127 doi http://dx.doi.org/10.1016/S0022$\underline{0981(96) 02707-4}$ 
Kleypas JA, McManus JW, Meñez LA (1999) Environmental limits to coral reef development: where do we draw the line? Am Zool 146-159

450 Klinger TS, Lawrence JM (1985) Distance perception of food and the effect of food quantity on feeding behavior of Lytechinus variegatus (Lamarck)(Echinodermata: Echinoidea). Mar Freshw Behav Physiol 11: 327-344

Klumpp DW, Salita-Espinosa J, Fortes M (1993) Feeding ecology and trophic role of sea urchins in a tropical seagrass community. Aquat Bot 45: 205-229

Ling S, Johnson C (2009) Population dynamics of an ecologically important range-extender: kelp beds versus sea urchin barrens. Mar Ecol Prog Ser 374: 113-125

Ma Y, Cohen SR, Addadi L, Weiner S (2008) Sea Urchin Tooth Design: An “All-Calcite” Polycrystalline Reinforced Fiber Composite for Grinding Rocks. Adv Mater 20: 1555-1559 Mamelona J, Pelletier É (2005) Green urchin as a significant source of fecal particulate organic matter

Manullang C, Tsuchiya M, Ambariyanto A, Permata D (2014) Impact Test Size and Type of

Muthiga N (2003) Coexistence and reproductive isolation of the sympatric echinoids Diadema savignyi Michelin and Diadema setosum (Leske) on Kenyan coral reefs. Mar Biol 143: 669677 
Scheibling R (1986) Increased macroalgal abundance following mass mortalities of sea urchins (Strongylocentrotus droebachiensis) along the Atlantic coast of Nova Scotia. Oecologia 68: $186-198$

Scoffin T, Stearn C, Boucher D, Frydl P, Hawkins C, Hunter I, MacGeachy J (1980) Calcium carbonate budget of a fringing reef on the west coast of Barbados. Part II Erosion, sediments and internal structure. Bull Mar Sci 30: 475-508

Thilakarathna R (2017) Study of a sea urchin Centrostephanus tenuispinus (Clark, 1914) population at Hall Bank reef, Western Australia, with special emphasis on its impacts on the reef. Doctoral Dissertation, Murdoch University Western Australia

Thomson DP, Frisch AJ (2010) Extraordinarily high coral cover on a nearshore, high-latitude reef in south-west Australia. Coral Reefs 29: 923-927 doi 10.1007/s00338-010-0650-1

Tribollet A, Decherf G, Hutchings PA, Peyrot-Clausade M (2002) Large-scale spatial variability in bioerosion of experimental coral substrates on the Great Barrier Reef (Australia): Importance of microborers. Coral Reefs 21: 424-432

Tuya F, Boyra A, Sanchez-Jerez P, Barbera C, Haroun RJ (2004) Relationships between rocky-reef fish assemblages, the sea urchin Diadema antillarum and macroalgae throughout the Canarian Archipelago. Mar Ecol Prog Ser 278: 157-169

Vanderklift M, Lavery P, Waddington K (2009) Intensity of herbivory on kelp by fish and sea urchins differs between inshore and offshore reefs

Vanderklift MA, Kendrick GA (2004) Variation in abundances of herbivorous invertebrates in temperate subtidal rocky reef habitats. Mar Freshw Res 55: 93-103

Vanderklift MA, Kendrick GA (2005) Contrasting influence of sea urchins on attached and drift macroalgae. Mar Ecol Prog Ser 299: 101-110

Vanderklift MA, Kendrick GA, Smit AJ (2006) Differences in trophic position among sympatric sea urchin species. Estuar Coast Shelf Sci 66: 291-297

Wells FE, Keesing J (1989) Reproduction and feeding in the abalone Haliotis roei Gray. Mar Freshw Res 40: 187-197 


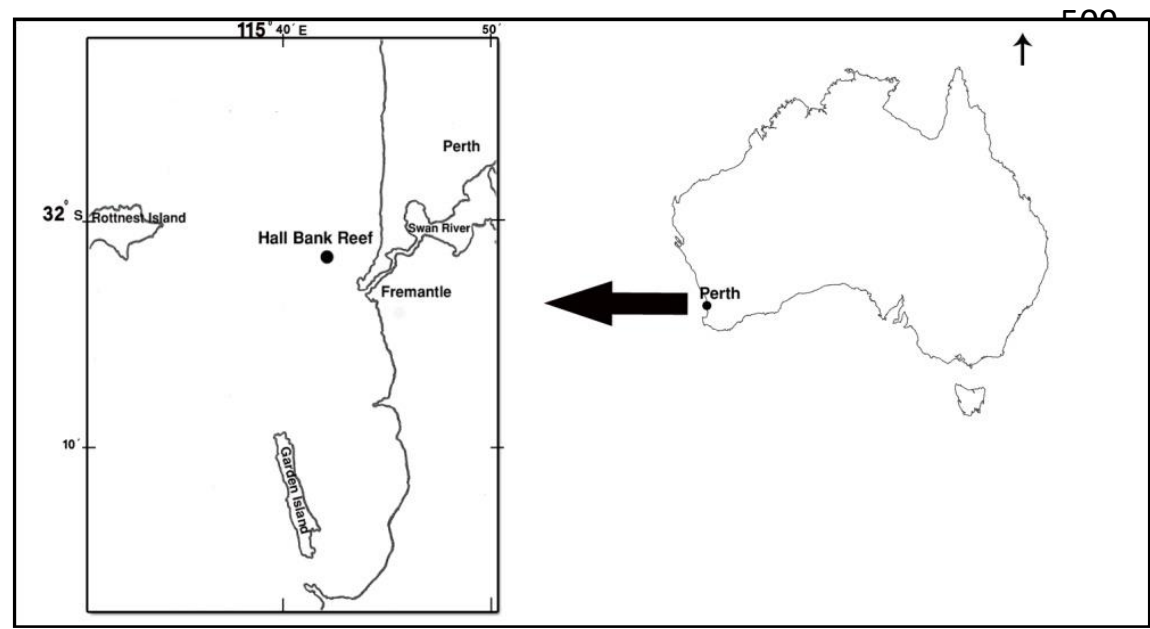

518 Figure 1. Map showing location of the Hall Bank reef in Western Australia.

519

520

521

522

523

524

525

526

527

528

529

530

531

532

533

534

535 


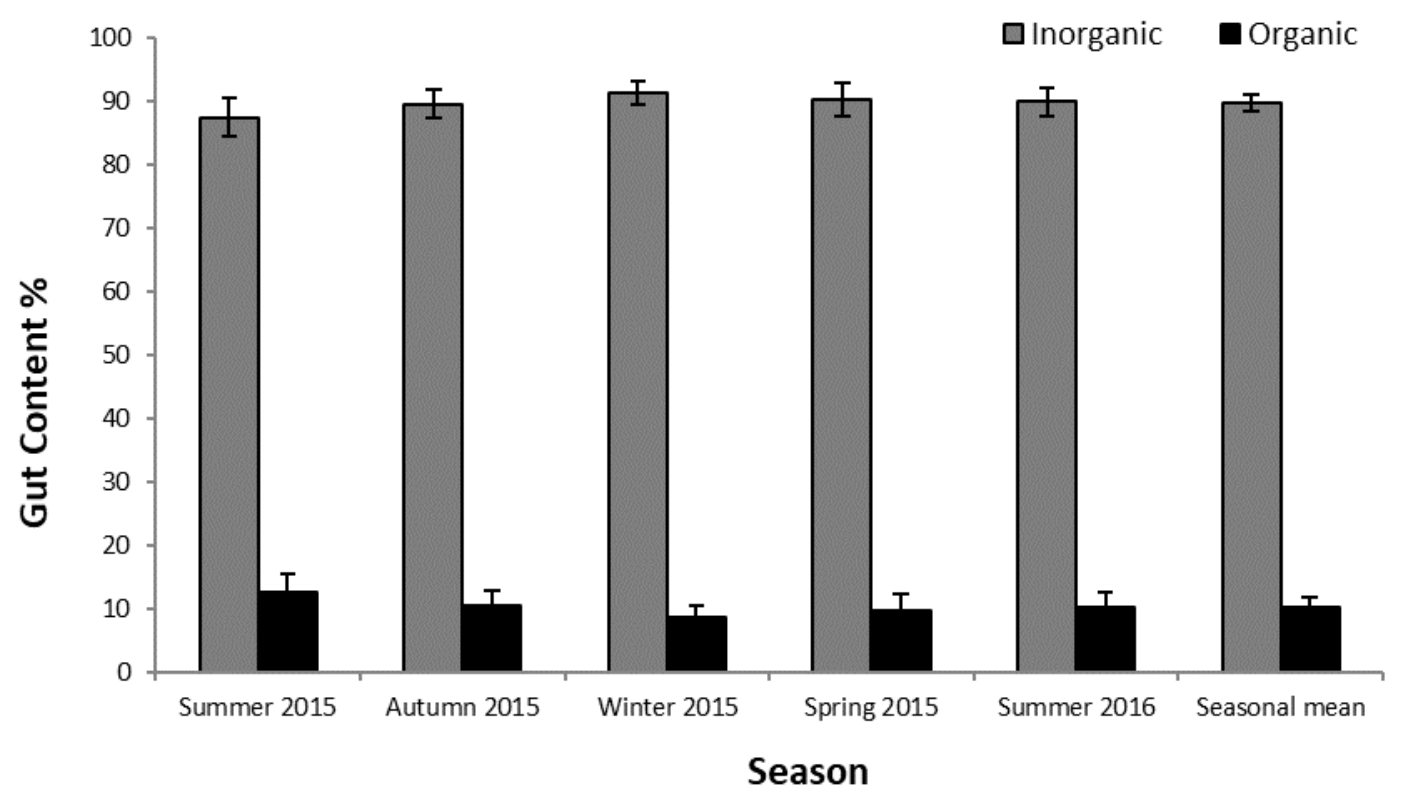

Figure 2. Seasonal mean proportions of inorganic (mean \pm SD) and organic (mean \pm SD) 


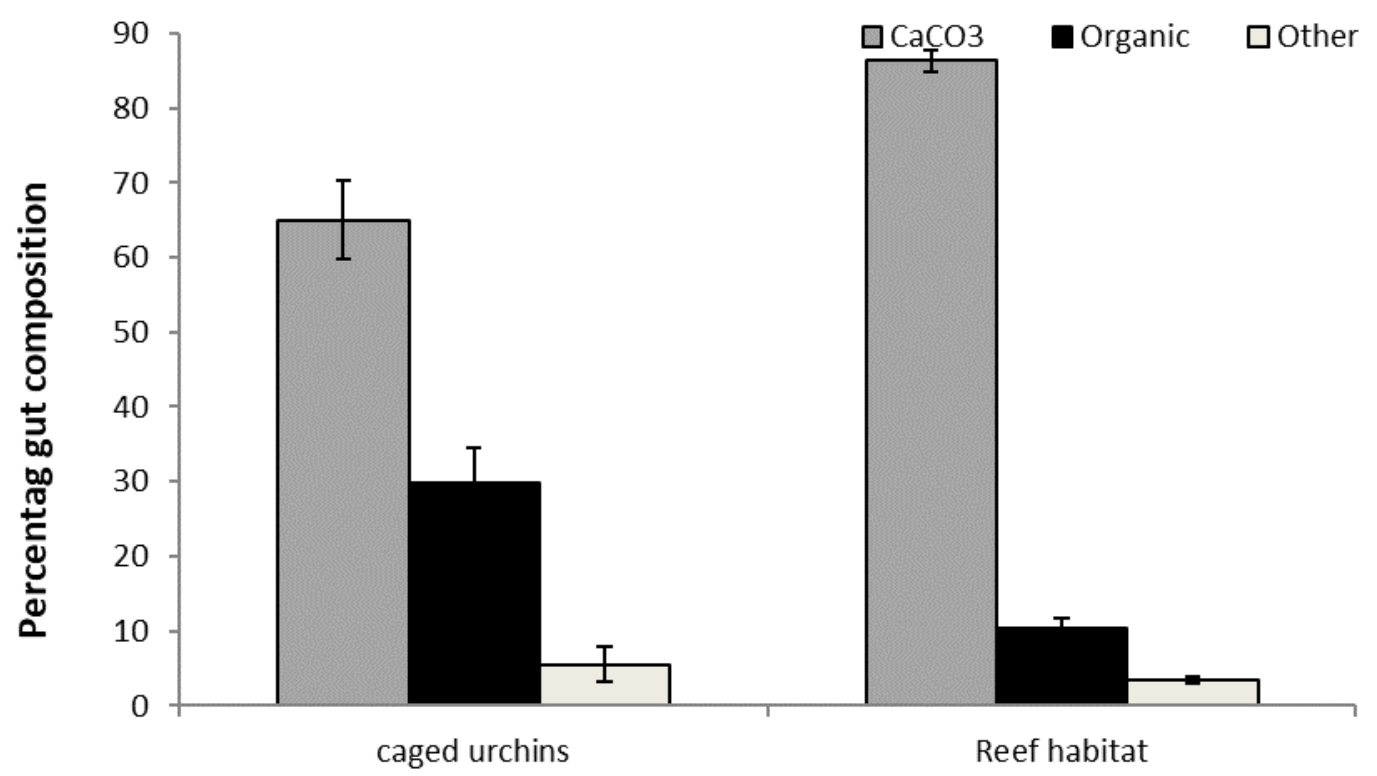

Figure 3. Composition of $C$. tenuispinus mean dry gut components in sampled population $(\mathrm{n}=364)$ and caged population $(\mathrm{n}=30)$. 


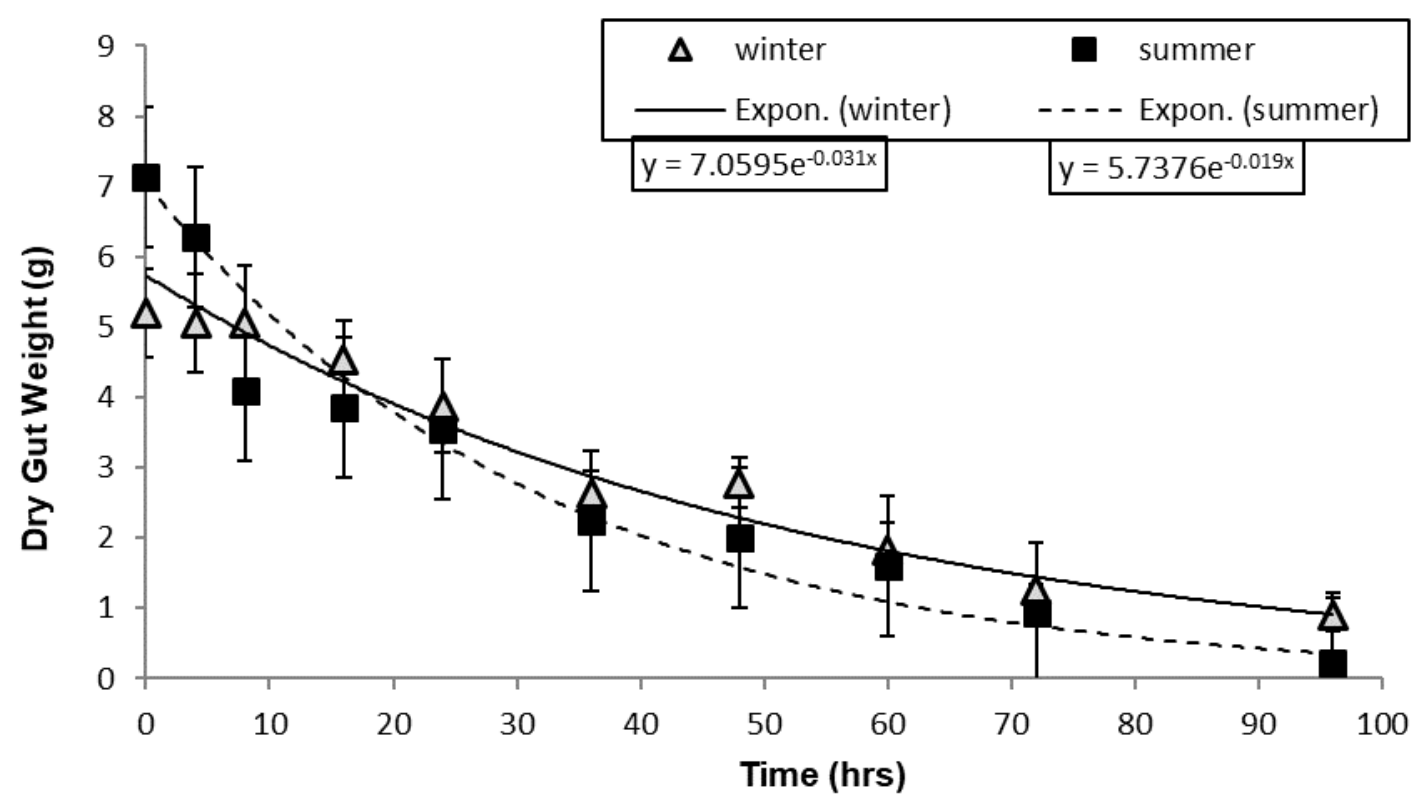

Figure 4. Gut evacuation of C. tenuispinus over $96 \mathrm{~h}$ in winter $(\mathrm{n}=50) 2015$ and summer $2016(\mathrm{n}=$ 50), Exponential curve fitted by least regression on the natural logarithms of dry gut weight with time. 
598 Table 1. Mean density, mean test diameter, mean gut weight, gut turnover rate and food ingestion rate 599 of C. tenuispinus (mean $\pm \mathrm{SD}, \mathrm{n}=364$ ).

\begin{tabular}{|c|c|c|c|c|c|}
\hline Season & $\begin{array}{l}\text { Mean sea } \\
\text { urchin } \\
\text { density } \\
\text { (individuals } \\
\mathrm{m}^{-2} \text { ) }\end{array}$ & $\begin{array}{l}\text { Mean test } \\
\text { diameter }(\mathrm{mm})\end{array}$ & $\begin{array}{l}\text { Mean gut } \\
\text { weight }(\mathrm{g})\end{array}$ & $\begin{array}{l}\text { Gut turnover } \\
\text { rate }\left(\mathrm{g} \mathrm{day}^{-1}\right)\end{array}$ & $\begin{array}{l}\text { Food ingestion rate gut dry } \\
\text { weight ( } \mathrm{g}_{\text {individual }}^{-1} \text { day }^{-} \\
\left.{ }^{1}\right) \text {. }\end{array}$ \\
\hline Summer 2015 & $3.20 \pm 0.23$ & $67.70 \pm 5.95$ & $6.48 \pm 1.33$ & 0.72 & $4.67 \pm 0.96$ \\
\hline Autumn 2015 & $3.45 \pm 0.29$ & $67.79 \pm 2.94$ & $6.54 \pm 1.37$ & 0.70 & $4.58 \pm 0.96$ \\
\hline Winter 2015 & $3.65 \pm 0.30$ & $68.61 \pm 6.47$ & $6.75 \pm 1.63$ & 0.24 & $1.62 \pm 0.39$ \\
\hline Spring 2015 & $3.73 \pm 0.33$ & $67.46 \pm 5.75$ & $7.31 \pm 2.02$ & 0.48 & $3.51 \pm 0.97$ \\
\hline Summer 2016 & $3.20 \pm 0.23$ & $68.06 \pm 5.37$ & $6.98 \pm 1.95$ & 0.72 & $5.02 \pm 1.33$ \\
\hline
\end{tabular}

600

601

602

603

604

605

606

607

608

609

610

611

612

613

614

615

616

617

618

619

620 
621 Table 2. Herbivory rate, $\mathrm{CaCO}_{3}$ ingestion rate, percentage newly eroded $\mathrm{CaCO}_{3}$ and bio-erosion rate 622 of $C$. tenuispinus (mean $\pm \mathrm{SD}, \mathrm{n}=364$ ).

\begin{tabular}{lllll}
\hline Season & $\begin{array}{l}\text { Herbivory } \\
\text { rate }(\mathrm{g} \\
\text { individual } \\
\left.\text { day }^{-1}\right)\end{array}$ & $\begin{array}{l}\mathrm{CaCO}_{3} \text { ingestion rate }(\mathrm{g} \\
\left.\mathrm{CaCO}_{3} \text { individual }^{-1} \text { day }^{-1}\right)\end{array}$ & $\begin{array}{l}\text { Newly eroded } \\
\text { percentage of } \\
\mathrm{CaCO}_{3} \text { in gut }\end{array}$ & $\begin{array}{l}\text { Bio-erosion rate } \\
\mathrm{g} \mathrm{CaCO}_{3} \text { individual }^{-1} \\
\left.\text { day }^{-1}\right)\end{array}$ \\
\hline Summer2015 & $0.58 \pm 0.18$ & $3.92 \pm 0.83$ & $18.83 \pm 3.73$ & $0.88 \pm 0.26$ \\
Autumn2015 & $0.47 \pm 0.14$ & $3.97 \pm 0.85$ & $21.60 \pm 2.36$ & $0.99 \pm 0.24$ \\
Winter2015 & $0.14 \pm 0.05$ & $1.41 \pm 0.34$ & $22.30 \pm 2.69$ & $0.36 \pm 0.09$ \\
Spring2015 & $0.34 \pm 0.14$ & $3.06 \pm 0.85$ & $22.19 \pm 2.73$ & $0.78 \pm 0.24$ \\
Summer2016 & $0.50 \pm 0.13$ & $4.36 \pm 1.18$ & $21.67 \pm 2.97$ & $1.10 \pm 0.36$ \\
\hline
\end{tabular}

623

624

625

626

627

628

629

630

631

632

633

634

635

636

637

638

639

640

641

642

643

644

645 
646 Table 3: Mean seasonal bio-erosion and annual bio-erosion in Hall Bank reef

\begin{tabular}{llll}
\hline Season & $\begin{array}{l}\text { Daily bio-erosion g } \\
\text { of } \mathrm{CaCO}_{3} \mathrm{~m}^{-2} \text { day }^{-1}\end{array}$ & $\begin{array}{l}\text { Seasonal erosion g } \\
\text { of } \mathrm{CaCO}_{3} \mathrm{~m}^{-2}\end{array}$ & $\begin{array}{l}\text { Annual bio-erosion g of } \mathrm{CaCO}_{3} \\
\mathrm{~m}^{-2} \mathrm{a}^{-1}\end{array}$ \\
\hline Autumn 2015 & 3.42 & 314.64 & 1017.69 \\
Winter 2015 & 1.32 & 121.44 & \\
Spring 2015 & 2.91 & 264.81 & \\
Summer 2016 & 3.52 & 316.80 & \\
\hline
\end{tabular}

647

648

649

650

651

652

653

654

655

656

657

658

659

660

661

662

663

664

665

666

667

668

669

670 
671 Table 4. Test diameter, mean dry gut weight, food ingestion rates, gut turnover rates, daily bio-erosion 672 rates of sea urchins Diadema setosum, D. savygnyi, Echinothrix diadema and C. tenuispinus (mean \pm $673 \mathrm{SD})$.

\begin{tabular}{|c|c|c|c|c|}
\hline Species & $\begin{array}{l}\text { Diadema } \\
\text { setosum } \\
\text { Carreiro-Silva } \\
\text { and } \\
\text { McClanahan } \\
(2001) \\
\end{array}$ & $\begin{array}{l}\text { Diadema } \\
\text { savignyi } \\
\text { Carreiro-Silva } \\
\text { and } \\
\text { McClanahan } \\
(2001) \\
\end{array}$ & $\begin{array}{l}\text { Echinothrix } \\
\text { diadema } \\
\text { Carreiro-Silva and } \\
\text { McClanahan } \\
\text { (2001) }\end{array}$ & $\begin{array}{l}\text { Centrostephanus } \\
\text { tenuispinus } \\
\text { (This } \\
\text { study/summer) }\end{array}$ \\
\hline Test diameter (mm) & $67.74 \pm 0.88$ & $69.86 \pm 0.98$ & $103.96 \pm 1.02$ & $69.06 \pm 0.61$ \\
\hline Mean gut weight (g) & $7.05 \pm 0.98$ & $3.48 \pm 0.78$ & $18.54 \pm 3.10$ & $6.98 \pm 0.21$ \\
\hline $\begin{array}{l}\text { Food ingestion rate (gut dry } \\
\text { weight individual }{ }^{-1} \text { day }^{-1} \text { ) }\end{array}$ & $8.34 \pm 1.16$ & $3.11 \pm 0.70$ & $21.09 \pm 3.52$ & $5.02 \pm 0.15$ \\
\hline Gut turnover rate $\left(\right.$ day $\left.^{-1}\right)$ & 1.18 & 0.89 & 1.14 & 0.72 \\
\hline $\begin{array}{l}\text { Bio-erosion rate } \\
\left(\mathrm{g} \mathrm{CaCO}_{3} \text { individual }^{-1} \text { day }^{-1}\right)\end{array}$ & $1.79 \pm 0.25$ & $0.72 \pm 0.16$ & $5.49 \pm 0.91$ & $1.10 \pm 0.04$ \\
\hline
\end{tabular}

